\title{
Utilization of bus tree wood (Melaleuca sp) as environmentally friendly fuel for household industrial scale Aluminum smelting stoves in Merauke, Papua
}

\author{
Klemens A Rahangmetan*, Cipto Cipto, Christian Wely Wullur, Farid Sariman, Hariyanto Hariyanto \\ Department of Mechanical Engineering, Faculty of Engineering, Universitas Musamus, Merauke 99600, Indonesia
}

\begin{abstract}
The purpose of this study is the use of bus wood trees as fuel for aluminum smelting for the home industry because it has a good heating value and is very efficient, from the laboratory test results, the bus tree wood has a calorific value of 5981 (calories/g). The methods used experimental and analytical to get the results from the use of bus wood as fuel for aluminum smelting which will certainly produce good mechanical properties. The results obtained a good combustion process that releasing all the heat contained in a fuel and done with three combustion control processes, including a fairly high temperature to ignite and maintain the flame of the fuel, turbulence or mixing $\mathrm{O}_{2}$ and the use of good fuel and sufficient time to complete combustion process. The fuel (bus wood) which is inputted in the furnace is designed so that the combustion process takes place more completely with minimal heat losses. The results of temperature changes seem a thermocouple and crucible furnace insulator material were very good heat resistance hence the time of the melting process it doesn't take longer which is 15 minutes. The aluminum in crucibles has melted at a temperature of $723^{\circ} \mathrm{C}$.
\end{abstract}

Keywords: Wood fuel bus; Aluminum melting; Household scale industry

\section{Introduction}

Merauke regency is the easternmost region of the Unitary State of the Republic of Indonesia and is one of 29 regencies/cities in Papua Province, this regency borders directly with the State of Papua New Guinea. Located between 1370 - 1410 east longitude and $5000^{\prime} 9$ 00 'LS with an area of $45,071 \mathrm{Km}^{2}$ it has very good natural potential with forest area reaching \pm 40.5 million $\mathrm{Ha}$ [1], therein is a natural heritage in the form of homogeneous and heterogeneous forests with a variety of plants in it, especially specifically the bus tree which is a plant that is mostly found in the Merauke forest. Bus wood is a typical wood of the Merauke district, which is certainly used as local fuel for the people of Merauke because it has a good calorific value from the results of laboratory tests of 5981 (calories/g), bus wood also has an economical price to be used as fuel for smelting metal (aluminum).

Businesses that are engaged in metal casting have been carried out by the public in both small and large categories, the media or tools used mainly in melting, namely the furnace which is the main tool for melting in metal and non-metal casting. To get a liquid material that has good results, the casting furnace is used, the raw material and the type of furnace to be used must be in accordance with the melted material, the use of a krusible furnace is one type of furnace used for aluminum melting (Al).

The process of melting aluminum metal can be done with wood charcoal, coconut shell charcoal, coal briquettes, kerosene and LPG gas using a simple crucible furnace. This furnace does not produce ash from combustion. However, kerosene and diesel fuel are currently rather difficult to procure and the price is relatively high, if reidu oil is used the risk of air pollution is higher, so using wood-fueled buses certainly does not require a large cost because bus wood is widely available in Merauke district and continues to be preserved by the local government aside from being a fuel it also produces oxygen for people who live in Merauke district. Similarly, making molds and patterns does not require expensive special equipment.

Crucible furnaces can be categorized according to the type of material that will be used in casting Aluminum, namely coke or charcoal, oil and gas [2], but in general construction from the use of which is often used is the same as using a pot or kowi or crucible as a container for smelting. Aluminum is a type of lightweight material that is widely consumed, not only for its own purposes but also for the needs of aircraft companies, cars, ships and other construction materials. $\mathrm{Al}$ alloy is not difficult to melt because it has a melting temperature of $600^{\circ} \mathrm{C}-700^{\circ} \mathrm{C}$ Therefore, casting $\mathrm{Al}$ is

\footnotetext{
* Corresponding author :krahangmetan@unmus.ac.id
} 
widely applied to companies both in small [3], medium and large This allows casting to be carried out in small industries where the availability of energy and machinery is limited. Besides the mechanical properties of this alloy, especially its hardness value can be improved by taking into account casting process parameters such as pouring temperature and melting temperature [4]. To get good aluminum smelting results, it must be supported by several important aspects such as the smelting furnace and the fuel used, so the purpose of this study is the use of wood buses as aluminum smelting fuels for household scale.

\section{Research Methods}

\subsection{Time and Place of Observation}

The method used is experimental and analytical methods so that to get the results of the use of wood as a fuel for aluminum smelting with good hardness value, of course the melting process will produce good results because the heating value contained in the furnace will be stable. This research began in January 2020. The research site was at the Laboratory of Mechanical Engineering at Musamus University. Interventionary studies involving animals or humans, and other studies require ethical approval must list the authority that provided approval and the corresponding ethical approval code.

\subsection{The Process Of Conducting Research}

The bus wood is shaped (cut) with a length of $15 \mathrm{~cm}$ and a width of $7 \mathrm{~cm}$, after that the input bus wood that has been cut into the aluminum melting furnace with aluminum base alloy is casted using a home industry scale $6 \mathrm{~kg}$ Crisbile furnace. The furnace, whose fuel is made of wood from the bus, has room for the combustion process where it is heated in the workpiece, at a certain temperature and held for a certain time interval. In order to warm up optimally, we need a furnace that is able to hold the heat to remain inside the furnace [5], for the wood bus image seen in Figure 1.

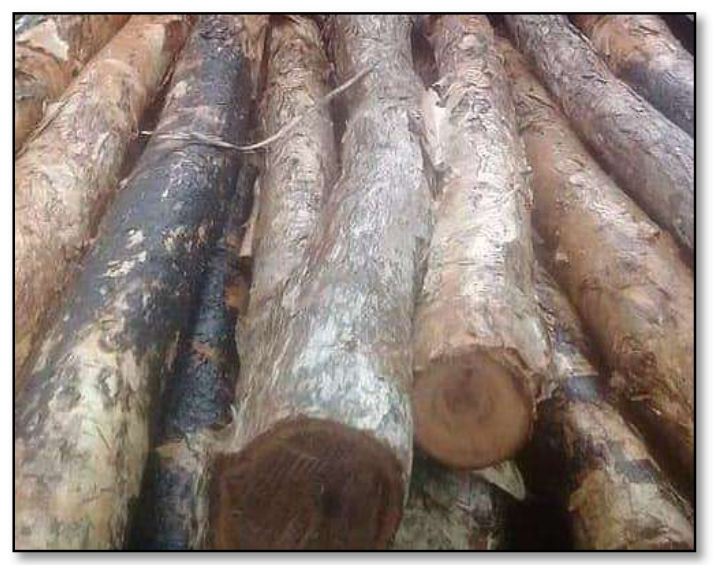

Fig. 1. Bus wood used as fuel
The design of the aluminum melting furnace with bus wood fuel with red brick material and coated plate as high as $450 \mathrm{~mm}$ long by $400 \mathrm{~mm}$, width $400 \mathrm{~mm}$ thick by $100 \mathrm{~mm}$. Combustion using wood fuel bus and placement of blower at the back of $1500 \mathrm{~mm}$ length with $2.50 \mathrm{~mm}$ diameter of furnace lid using red brick covered by iron plate which is $450 \mathrm{~mm}$ high, $400 \mathrm{~mm}$ long, 400 $\mathrm{mm}$ long and $100 \mathrm{~mm}$ thick, for design drawings of chair stove design can be seen in Figure 2.

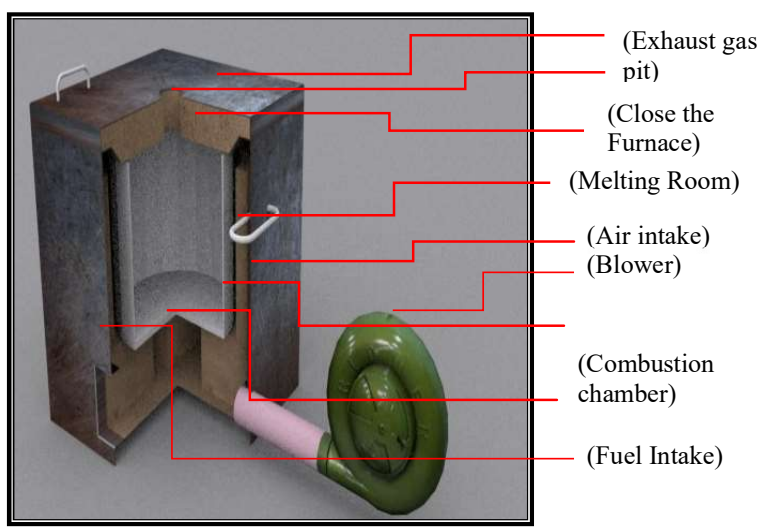

Fig. 2. Design of aluminum melting furnaces

\subsection{Burning Bus Wood In An Aluminum Melting Furnace}

A good combustion process that is releasing all the heat contained in a fuel, this will certainly be done with three combustion control processes including a fairly high temperature temperature to ignite and maintain the flame of the fuel, turbulence/turbulence or mixing $\mathrm{O}_{2}$ and the use of fuel good and the time/time needed is enough for the perfect combustion process. The fuel (wood bus) that is fed into the smelter (kitchen) is designed so that the combustion process takes place more perfectly with minimal heat losses. With this design, it is expected that the fuel needed for the smelting process can be saved and the resulting environmental impact can also be minimized.

\section{Results and Discussion}

\subsection{Description Of Research Results}

The initial process is done first, measuring room temperature or room temperature in the furnace before the aluminum melts the test by first entering the bus wood in the furnace and lighting the fire with the help of a wind push on the blower, then inserting aluminum into the kowi [6]. The result of the temperature change is seen by using the thermopel which is done and the crucible furnace has a very good heat resistance so that when the melting process does not require a very long time that is 15 minutes Aluminum in krusibe has melted at $723^{\circ} \mathrm{C}$, it can be seen that the heating value which is produced by bus wood that is widely available in Merauke district has enormous benefits to be used as fuel for aluminum smelting and this will continue to be 
developed so that local communities can utilize bus wood as a livelihood in the development of the household-scale foundry industry. for pictures of the operation of the Aluminum melting furnace with bus wood fuel can be seen in figure 3 and 4 .

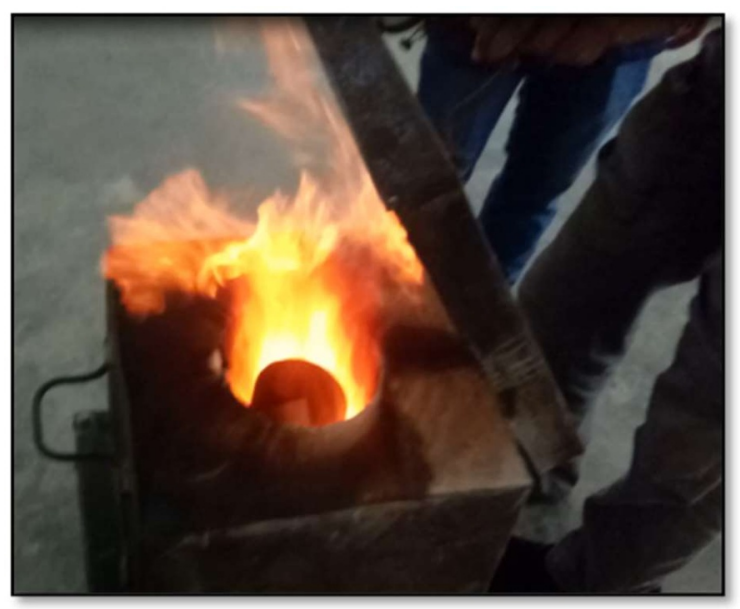

Fig. 3. The process of operating an Aluminum melting furnace with wood-fueled buses

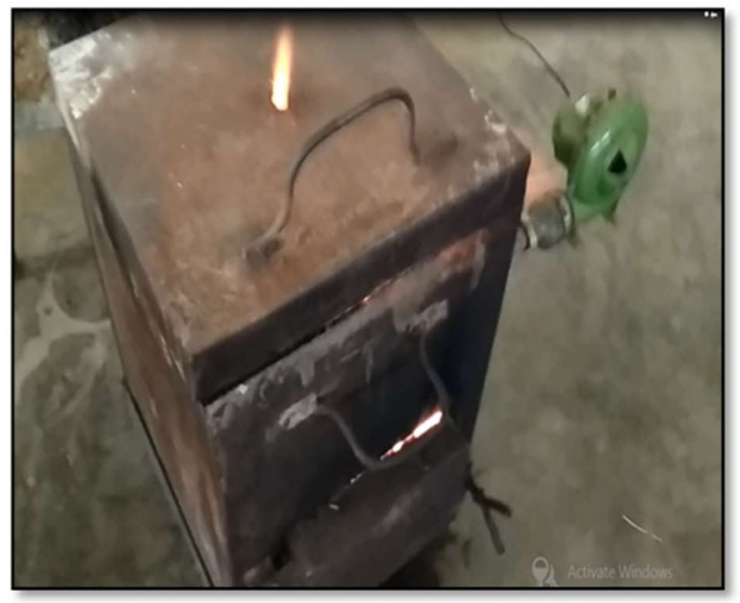

Fig. 4. Design of aluminum melting furnaces

The wood of the bus used to melt aluminum in the melting furnace has very good heat so that the aluminum contained in the crucible can easily melt $2 \mathrm{~kg}$ of aluminum in 7 minutes, but the time needed to melt the aluminum point is \pm 15 minutes and the time required until it reaches a temperature of $723^{\circ} \mathrm{C}$ is 24 minutes. The amount of fuel used to reach a temperature of $723^{\circ} \mathrm{C}$ is $\pm 4 \mathrm{~kg}$. This means that the fuel requirement for aluminum smelting is $1.5 \mathrm{~kg}$ of fuel per $\mathrm{kg}$ of aluminum. The magnitude of the rate of combustion of this fuel is smaller when compared to a diesel-fueled melting furnace that requires 5.8 liters with a melting time of 50 - 55 minutes, while using used oil requires 6 liters, and requires a melting time of $60-65$ minutes. Bus wood certainly has a very good calorific value and has the advantage that it can be used as fuel for the aluminum casting business for local communities in Merauke district. Aluminum was chosen as the metal to be melted because aluminum has a large volume volume with a small density and melting point at a temperature of $660^{\circ} \mathrm{C}$, so that the bus wood with a very good heating value can be utilized as fuel for the aluminum melting process. Aluminum that is commonly found in the form of scrap is widely used as an aluminum metal casting material and which is often used for recycling.

The results of the observation of the combustion chamber contained in the aluminum melting furnace with bus wood fuel is very good because the fire from the wood burning bus is very perfect and is also supported by a wall of a crucial furnace made of good insulating material so that the heat generated by burning the wood of the bus is burning inside the furnace cannot come out so that the aluminum contained in the melting furnace does not require a long time to be melted them.

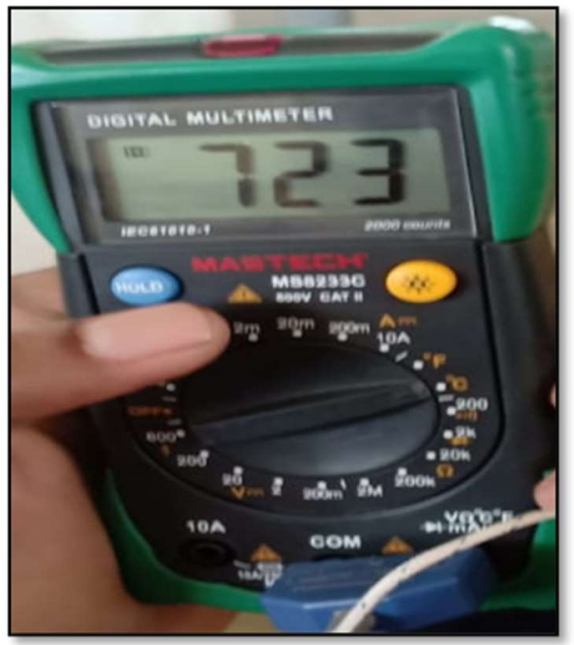

Fig. 5. Design of aluminum melting furnaces

\section{Conclusion}

The conclusions of this study are:

1. Forest potential in Merauke Regency, apart from being an $\mathrm{O}_{2}$ (oxygen) producer, can also be used as a livelihood for local people who will develop a home industry in the field of metal casting, to exploit the potential of the forest, especially bus forests which are abundant in the district area Merauke.

2. The bus wood used to melt aluminum has a very good heating value of 5981 (calories/g) so that melting aluminum with melting temperature of $600^{\circ} \mathrm{C}-700^{\circ} \mathrm{C}$ does not require a long time which is 15 minutes with a temperature of $723^{\circ} \mathrm{C}$.

\section{References}

1. Kamus Besar Bahasa Indonesia, Edisi Keti. Jakarta: PT. Balai Pustaka, (2011).

2. A. Leman, T. Tiwan, "Tungku Krusibel dengan Economizer untuk Praktik Pengecoran di Jurusan Pendidikan Teknik Mesin FT UNY," Din. VOKASIONAL Tek. MESIN, (2017).

3. Klemens A. Rahangmetan ${ }^{1}$, Cipto ${ }^{1}$, "Study on effect of temperature smelting and pouring to mechanical 
properties Aluminum 7075., "IOP Conf. Ser. Earth Environ. Sci., vol. 1, no. 343, p. 012166, (2019).

4. Tugiman", Suprianto ${ }^{2}$, "Studi Pengaruh Temperatur Tuang Terhadap Sifat Mekanis Pada Pengecoran Paduan Al-4,3\%Zn Alloy," (2013).

5. Klemens A. Rahangmetan, Christian Wely Wullur, "Pengaruh bentuk saluran atas dengan riser untuk mengurangi cacat coran pada pengecoran propeller kapal dengan paduan al7075., "MJEME, vol. 1, no. 1, (2018).

6. H. Sudjana, Teknik Pengecoran, Jilid 1. Direktorat Sekolah Menengah Kejuruan, Jakarta., (2008). 